\title{
Growth and maturity of sprat (Sprattus sprattus) in the Kattegat and Skagerrak, eastern North Sea
}

\author{
Francesca Vitale $^{1}$, Felix MitTermaYer ${ }^{1,2}$, Birgitta Krischansson ${ }^{1}$, Marianne JOHANSSON ${ }^{1}$ \\ and Michele CASINI ${ }^{1, a}$ \\ 1 Swedish University of Agricultural Sciences, Department of Aquatic Resources, Institute of Marine Research, 45330 Lysekil, Sweden \\ 2 GEOMAR Helmholtz Centre for Ocean Research, Evolutionary Ecology of Marine Fishes, 24105 Kiel, Germany
}

Received 13 July 2015; Accepted 12 February 2016

\begin{abstract}
Information on fish biology, as growth and reproduction, is an essential first step for a sound assessment and management of a fishery resource. Here we analyzed the annual cycle of body condition factor $(K)$, gonadosomatic index $(G S I)$ and maturity of sprat from the Skagerrak and Kattegat as well as from the Skagerrak inner fjords (Uddevalla fjords). The results show an inverse yearly pattern for $K$ and $G S I$ in both areas, $K$ being the highest in autumn and lowest in spring, while the GSI index was highest in spring and lowest in autumn. The annual highest proportion of spawning fish was recorded from May to July, indicating the late spring and early summer as the main spawning period for sprat in these areas. Male sprat reached maturity at a higher size in the Uddevalla fjords compared to Skagerrak and Kattegat, while negligible differences were shown by females. The $K$, GSI and size-at-age were the lowest in the Uddevalla fjords, while $K$ and $G S I$ were the highest in the Skagerrak, potentially related to the different environmental conditions encountered in the different areas. All in all the present results furnish important information about the biology of the sprat in the area that is highly relevant in stock assessment and management. The potentiality for the sprat inhabiting the Uddevalla fjords to be a different sub-population should be addressed through further investigations.
\end{abstract}

Keywords: Fish / energy allocation / yearly cycles / spawning time / spatial differences / stock assessment

\section{Introduction}

The European sprat (Sprattus sprattus) is a small marine pelagic clupeoid species spread throughout the Northeast Atlantic (Torstensen 1998; Power et al. 2000), the Baltic Sea (Kraus and Köster 2004; MacKenzie et al. 2008), the Adriatic Sea (Dulčić 1998) and the Black sea (Avsar 1995; Shulman et al. 2005). The sprat is a commercially highly valuable species, used for human consumption (canning), fishmeal and oil. Ecologically it has a twofold importance, as planktivore (Casini et al. 2004) and prey for piscivorous fishes, sea birds and marine mammals (Lundström et al. 2010; Dänhardt and Becker 2011).

The Skagerrak-Kattegat (Eastern North Sea), labelled as Division IIIa by the International Council for the Exploration of the Sea (ICES), is an area inhabited by a sprat population which has not received particular attention in research and literature during the past decades. Some work has been done on growth (Lindquist 1972) and temporal variations in mean length (Molander 1940; Torstensen and Gjøsæter 1995), milieu forms (Molander 1942), year classes strength (Lindquist 1966), as well as on meristic and morphometric characters

\footnotetext{
a Corresponding author: michele.casini@slu.se
}

(Lindquist 1968). Further dated work focused on the distribution and abundance of the sprat (Lindquist 1964) and sprat eggs and larvae (Lindquist 1970) in this area. In Skagerrak, egg and larval occurrence has been recorded along the whole Swedish and Norwegian coasts including the fjords and along the offshore water front between Skagerrak and Kattegat (Sund 1911; Lindquist 1970; Torstensen and Gjøsæter 1995), while very little information on early life history stages and spawning is available for the mid and southern Kattegat. Moreover, no study has investigated the gonadal maturation and seasonal variation of condition, neither in the Kattegat nor in the Skagerrak.

Although the commercial sprat fishery in the SkagerrakKattegat is not as relevant as in the adjacent Baltic Sea and North Sea, it can be relatively important on a local scale. The fishing in the Kattegat is conducted by Sweden and Denmark, with an annual average landing of about $1500 \mathrm{t}$ and $7500 \mathrm{t}$ respectively, over the last two decades. In the Skagerrak the catches are divided between Denmark (4100 t), Sweden (3000 t) and Norway (800 t) (ICES 2015a). The sprats are caught with different methods, i.e. smaller purse seiners and pelagic trawls, and also landed as by-catch in the herring (Clupea harengus) fishery. Currently the sprat fishery is 
controlled by by-catch ceilings of herring and by-catch percentage limits (ICES 2015a).

The biological knowledge of sprat in Skagerrak-Kattegat is very limited, and this contributes to the difficulties to perform an analytical stock assessment which could serve as quantitative base for management advice. This population is therefore currently considered a data limited stock (DLS) within ICES (ICES 2015a). Particularly, the lack of proper information on maturity patterns, such as timing of spawning and maturity ogives (i.e. proportion mature at length or age), has been raised as quality issue for stock assessment purposes (ICES 2013). Moreover, investigations of potential spatial differences in gonad maturation cycles, but also other key biological parameters such as size-at-age, are essential to perform data collection at the most appropriate spatial scale (ICES 2013).

In this study we investigated the seasonal changes in condition, gonad development and maturity in sprat from both the Kattegat and Skagerrak. Additionally we compared growth, in terms of length-at-age and weight-at-age, between the two areas. Most of the Skagerrak fjords have a direct connection to the open sea. Only the Uddevalla fjord system, due to its narrow passages and low water exchange, is relatively isolated from the open sea (Lindquist 1964). The life history parameters from samples collected in the Uddevalla fjord were therefore also scrutinized.

\section{Material and methods}

Fish sampling was performed, on a monthly basis when possible, between 2002 and 2004 in the areas of highest concentration of sprat (ICES 2013, ICES 2015a) in the Kattegat, the open Skagerrak (hereafter referred to as Skagerrak) and Skagerrak's inner fjord system (hereafter referred to as Uddevalla fjords) (Fig. 1). The Kattegat is constituted by a relatively shallow and uniform seafloor (average depth of $30 \mathrm{~m}$ ), whereas the Skagerrak is very deep in the centre of its basin $(>700 \mathrm{~m})$ but is characterized by shallow depth along the Swedish coast were the samples were taken. The inner Uddevalla fjords have an average depth of $20 \mathrm{~m}$ (maximum depth of $50 \mathrm{~m}$ ) and are relatively isolated from the Skagerrak hindering water exchange and creating local situations of hypoxia and anoxia. Each month, multiple samples were typically taken. The data were collected during different research surveys, namely IBTS (International Bottom Trawl Survey, by the Swedish R/V Argos, GOV-bottom trawl with $16 \mathrm{~mm}$ mesh size), acoustic surveys (by the Danish R/V Dana, pelagic Fotö-trawl with $16 \mathrm{~mm}$ mesh size) and Swedish Coastal Monitoring (by the Swedish R/V Ancylus, Nephrops-bottom trawl with $70 \mathrm{~mm}$ mesh size). Further samples were taken on board commercial fishing vessels (trawlers and purse seiners, 32 or $16 \mathrm{~mm}$ mesh size) operating in the area. From the hauls with a large sprat catch, a subsample of 50 individuals was taken, while if the catch was small ( $<50$ individuals) all fish were analysed. All samples were frozen before biological analyses. The sample size by area, month and year is shown in Table 1. Only in May and October/November all the three areas (Kattegat, Skagerrak and Uddevalla fjords) were sampled. The length frequency distribution, age structure and sex ratio of the samples from May and October/November are shown by area in

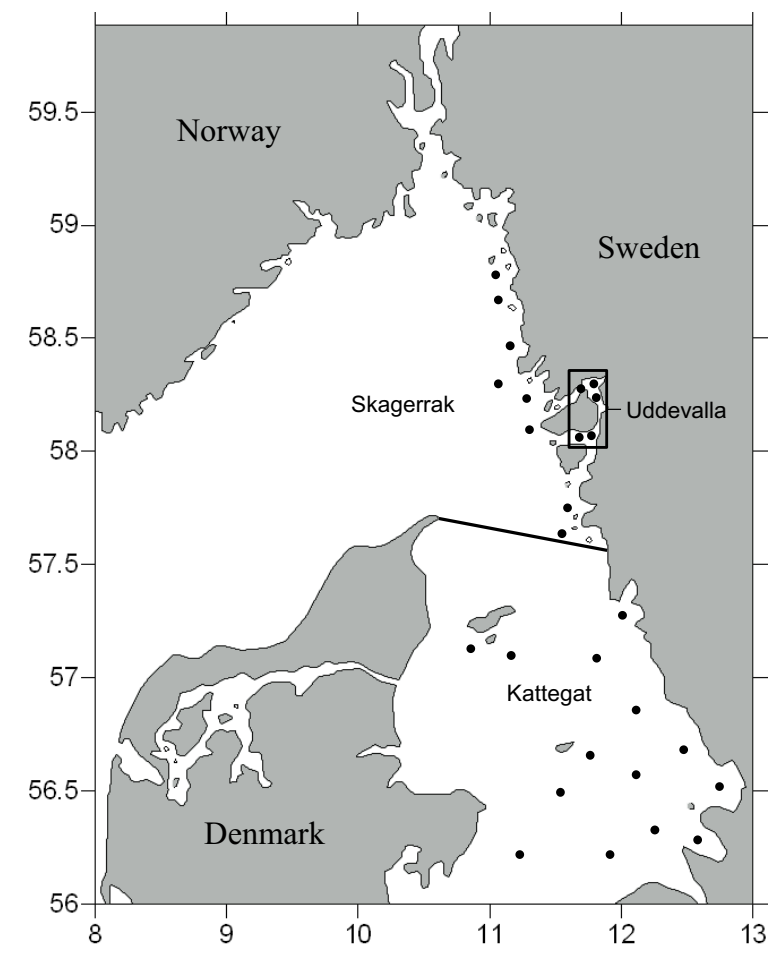

Fig. 1. Study area with the sampling stations.

the Appendix (Figs. A.1-A.3). Temperature and salinity seasonal variations in the study area are also shown in Appendix (Fig. A.4).

For each fish, the total length $(T L)$ to the mm below, total and gutted weight to the nearest $0.1 \mathrm{~g}$ ( $T W$ and $W g$, respectively), and gonads weight $(G W)$ to the nearest $0.001 \mathrm{~g}$, were recorded. The otoliths were extracted and used for individual age determination by counting the winter rings on the sagitta pairs. To ensure precision, the age was independently estimated by two scientists. Each individual was also sexed and its maturity was assessed macroscopically according to an eight-stage maturity scale based on gonads' size, consistency, colour and shape (Appendix, Table A.1). Individuals in stages III to VIII were considered as reproductively active, i.e. maturing and spawning in the next (or current) spawning season (III-VI) or having already spawned in the current spawning season (VII-VIII), whereas individuals in stages I and II were considered as reproductively inactive (Brown-Peterson et al. 2011).

These data were used to estimate the maturity ogives, i.e. the proportion of maturing fish at a given size for each area using a logistic (s-shaped) regression as follows:

$$
P_{i}=\frac{1}{1+\mathrm{e}^{-K\left(L_{i}-L 50\right)}}
$$

where $P_{i}$ is the proportion mature at length $\left(L_{i}\right)$ while $K$ and $L_{50}$ are the parameters to be estimated. $K$ represents the instantaneous rate of maturation, or the slope of the curve. $L_{50}$ represents the length at which $50 \%$ of the fish are mature. Maturity ogives were estimated using only May data, in which all the three areas were sampled by the same gear (Table 1), and corresponding to peak spawning (see the Results). 
Table 1. Sample size by area, month and year. In parenthesis are indicated the sampling vessels: Ar (R/V Argos), An (R/V Ancylus), D (R/V Dana) and C (Commercial).

\begin{tabular}{|c|c|c|c|c|}
\hline Year & Month & Kattegat & Skagerrak & Uddevalla \\
\hline \multirow[t]{2}{*}{2002} & November & $221(\mathrm{An}, \mathrm{C})$ & & \\
\hline & December & & $392(\mathrm{C})$ & \\
\hline \multirow[t]{10}{*}{2003} & January & & 1267 (C) & \\
\hline & February & 901 (Ar) & $882(\mathrm{C})$ & \\
\hline & March & $210(\mathrm{An}, \mathrm{C})$ & $96(\mathrm{An}, \mathrm{C})$ & \\
\hline & April & & $265(\mathrm{An}, \mathrm{C})$ & \\
\hline & May & 64 (An) & 107 (An) & $172(\mathrm{An})$ \\
\hline & July & 168 (D) & 67 (An) & \\
\hline & August & & $60(\mathrm{Ar})$ & \\
\hline & September & 457 (Ar) & $400(\mathrm{Ar})$ & \\
\hline & October & & $535(\mathrm{An})$ & 183 (An) \\
\hline & November & 47 (An) & $233(\mathrm{C})$ & \\
\hline \multirow[t]{11}{*}{2004} & January & 235 (Ar) & $198(\mathrm{C})$ & \\
\hline & February & 20 (An) & $201(\mathrm{Ar}, \mathrm{C})$ & \\
\hline & March & $175(\mathrm{An})$ & $230(\mathrm{C})$ & \\
\hline & April & & 401 (An, Ar) & \\
\hline & May & 109 (An) & 244 (An) & 129 (An) \\
\hline & June & & 37 (An) & \\
\hline & July & 131 (D) & & \\
\hline & August & & $62(\mathrm{Ar})$ & \\
\hline & September & 221 (Ar) & 110 (Ar) & \\
\hline & October & $163(\mathrm{C})$ & $503(\mathrm{An}, \mathrm{C})$ & $102(\mathrm{An})$ \\
\hline & November & $100(\mathrm{An}, \mathrm{C})$ & & \\
\hline
\end{tabular}

For each fish, two bionergetic indices were inspected.

A modified Fulton's condition index $(K)$ based on gutted weight $(W g)$ was estimated as follows:

$$
K=W g \times T L^{-3.17}
$$

where the exponent 3.17 is the slope of the overall regression between ln-length and ln-weight.

The condition factor is considered an index of the wellbeing, or fatness, of the fish and of the relative amount of energy allocated to body growth (Kondratjeva 1993).

The second index considered was the gonadosomatic index $(G S I)$, calculated as follows:

$$
G S I=G W \times W g g^{-1} \times 100
$$

where $G W$ is the gonad weight and $W g g$ is the weight of the fish with only guts removed but gonads still included.

GSI is considered an index of the relative amount of energy allocated to reproduction (Vitale et al. 2008).

Both indices were estimated monthly to explore the yearly cycle of their development.

General linear models (GLMs) were used to investigate $K$ and GSI annual cycles of development. The variables were transformed as sqrt $(G S I)$ and $\ln (K)$ to achieve a normal distribution (Shapiro-Wilk, $p>0.05$ ). In these analyses, $K$ and GSI were used as dependent variable and Month as independent variable, while Year, $T L$, Sex and Area were used as covariates.
GLMs and Fisher LSD Post-hoc tests were used to investigate potential differences in $K$ and GSI between the three areas. GLMs provide a test for the overall difference between the areas, while the Post-hoc test indicates what specific pairs of areas are different. The $K$, normally distributed, was used untransformed in the model as dependent variable, while Area was used as independent variable. The effects of Year, TL, Sex and Maturity stage were used as covariates in the model. Age was also tested instead of $T L$ as covariate but the results remained unchanged. The GSI, normally distributed when logtransformed, was used in the model as dependent variable, while Area was used as independent variable. The effects of Year, $T L$, Sex and Maturity stage were used as covariates in the model. Age was also tested instead of $T L$ as covariate but the results remained unchanged. In these analyses, we used only samples from May, corresponding to peak spawning (as shown by the maturity stage composition by month, see Results) and sampled in all three areas by the same gear (Table 1).

GLMs and Fisher LSD Post-hoc tests were also used to investigate potential differences in the growth rates of sprat in terms of weight-at-age (WAA) and length-at-age (LAA) in the study areas, using May and October/November samples, in which all the three areas were sampled by the same gear $(\mathrm{R} / \mathrm{V}$ Ancylus). This last model included $T L$ and $T W$ as dependent variables, while Area and Age as independent variables. The effects of Year, Month and Sex were used as covariates. Only age up to 6 years old were included in the models due to the scarcity of data for older age classes. 


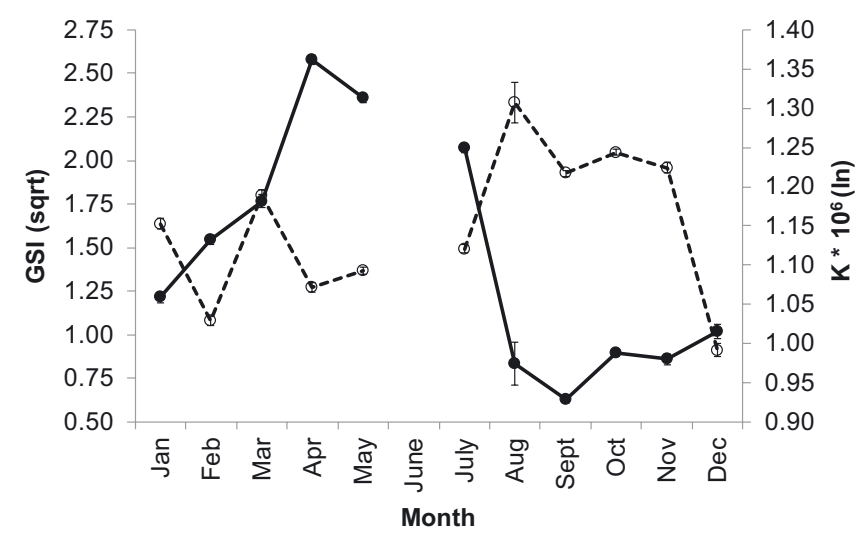

Fig. 2. Annual cycles in the Fulton condition index $(\ln K)$ and gonadosomatic index (sqrt GSI) for sprat in the study area. Vertical bars denote standard errors.

All the statistical analyses were performed using the program Statistica ${ }^{\circledR}$.

\section{Results}

\subsection{Annual cycles in condition, gonadosomatic index and maturity}

Significant seasonal changes in the $K[F(10,3554)=$ 236.06; $p<0.0001]$ and $G S I[F(10,3554)=759.69 ; p<$ $0.0001]$ were displayed by sprat in the study area (Fig. 2). The condition of sprat was highest in autumn and lowest in spring. An opposite yearly pattern was displayed by the GSI index, i.e. highest in spring and lowest in autumn. The statistics of the analyses are shown in Appendix (Tables A.2 and A.3).

The frequency distribution of the different maturity stages over the year for the three areas is shown in Figure 3.

In the Kattegat, fully developed individuals in prespawning condition (stages IV-V) were found already in January, but spawning fish (stage VI) were observed only from March until July. Stage II (i.e. inactive) fish were always present, but dominated the entire samples from September to November (i.e. after spawning). The increased presence of individuals in stage III during autumn indicates that sprat have started to build up new gonads for next year spawning. Specimens in stage VII (spent) and VIII (resting) were observed with low frequency during the spawning. Due to the low representativeness, the last two stages are visualized together in Figure 3.

The same pattern was shown also by the sprat in the Skagerrak. However spawning fish (stage VI) were detected already in February. Also in Skagerrak, fish caught during the autumn showed a development indicating the preparation for the next reproductive season (increase proportion of stage III), but individuals in an advanced developmental phase (stage IV) were already observed in October.

For what it concerns the Uddevalla fjords, all stages from juvenile to spent were observed in spring (May), with a predominance of stage VI, while mostly stages I-III were found in autumn (October). There were only 2 individuals recorded in stage IV in October.
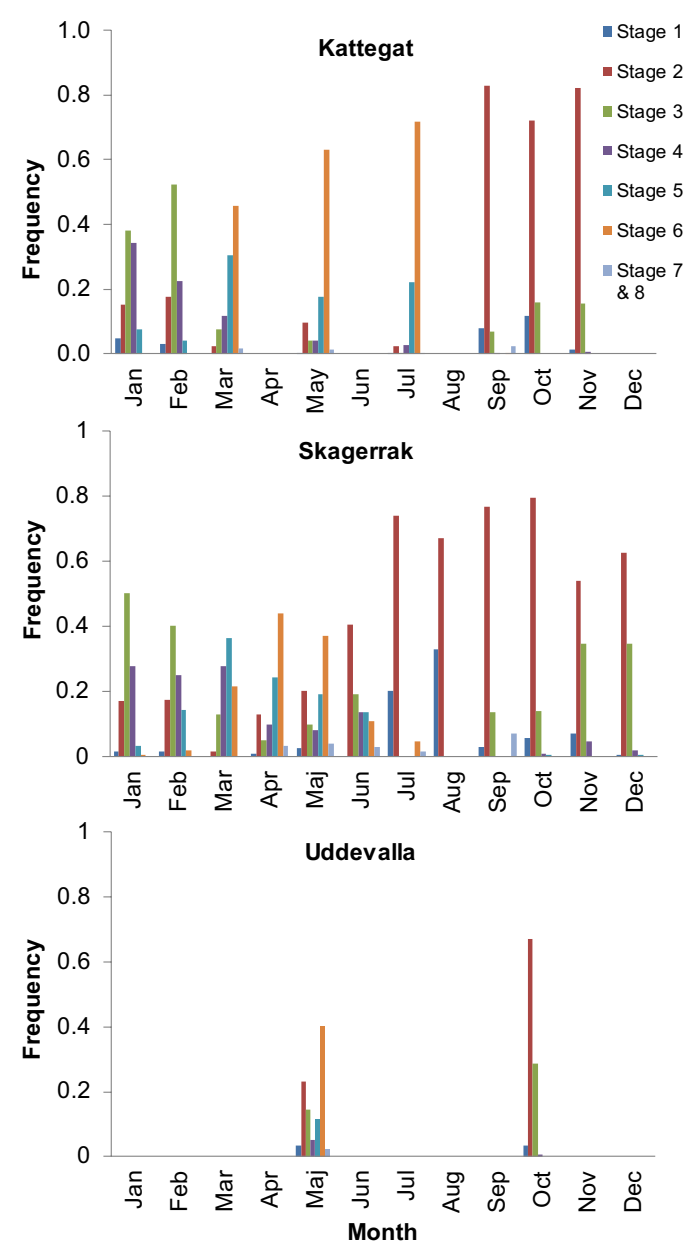

Fig. 3. Frequency distribution of maturity stages showing the seasonal changes in Kattegat (upper plot), Skagerrak (middle plot) and Uddevalla fjords (lower plot).

\subsection{Spatial differences in maturity ogives, bioenergetics indices and growth}

Sex separated maturity ogives are shown for each area in Figure 4. Males appear to become mature at a smaller size in Skagerrak and Kattegat $\left(L_{50}=90 \mathrm{~mm}\right)$ compared to the Uddevalla fjords $\left(L_{50}=100 \mathrm{~mm}\right)$. Females, on the other hand, did not show spatial differences, with an estimated $L_{50}=102 \mathrm{~mm}$ in all areas.

Significant differences among sprat from the different areas were detected for both $K[F(2,471)=43.08$; $p<0.0001]$ and $G S I[F(2,471)=33.88 ; p<0.0001]$. Fisher LSD Posthoc tests showed that these differences were significant among all the three study areas, for both $K$ and GSI. Specimens from the Skagerrak had highest $K$ and GSI whilst those from Uddevalla fjords showed the lowest values of those indices (Fig. 5). The statistics of the GLM analyses and LSD Post-hoc tests are shown in Appendix (Tables A.4 and A.5).

Significant differences among sprat from the different areas were detected also in growth, both in terms of $L A A$ $[F(12,1084)=10.24 ; p<0.0001]$ and $W A A[F(12,1084)=$ $11.37 ; p<0.0001]$. Significant was also the interaction Area $\times$ Age. Fisher LSD Post-hoc test showed that the 


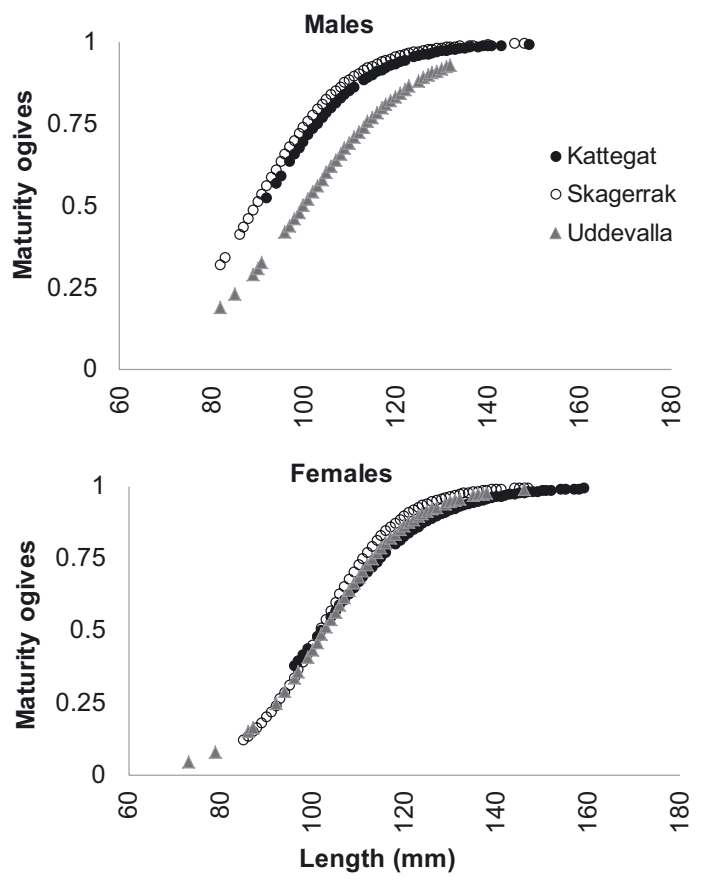

Fig. 4. Sex-separated maturity ogives by length in the Kattegat, Skagerrak and Uddevalla fjords.

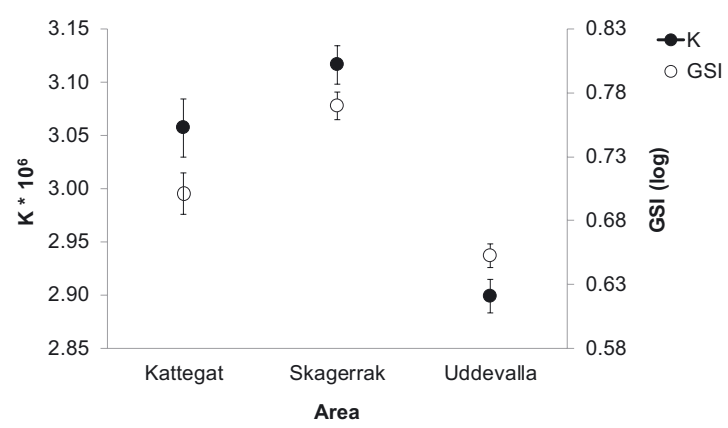

Fig. 5. Differences in Fulton condition index ( $K$, untransformed) and gonadosomatic index $(\log G S I)$ between Kattegat, Skagerrak and Uddevalla fjords. Vertical bars denote standard errors.

differences among areas were not significant for age 0 . For older fish, on the other hand, significant differences were consistently found between Uddevalla fjords and Kattegat/ Skagerrak: the individuals from the Uddevalla fjords were the smallest/leanest at the same age (Fig. 6). The statistics of the GLM analyses and LSD Post-hoc tests are shown in Appendix (Tables A.6 and A.7).

\section{Discussion}

The results of our study point to an extended spawning time of sprat, from early spring through the summer, in the studied area. The highest proportion of fish in spawning state (maturity stages V and VI) was in fact found between March and July, corresponding to a fast seasonal increase in water temperature (Appendix, Fig. A.4; for the Skagerrak, see also Lindquist 1964; for the Baltic Sea, see Kraus and Köster 2004) and therefore the onset of the annual plankton production. In our samples a very small proportion of spawning fish was al-
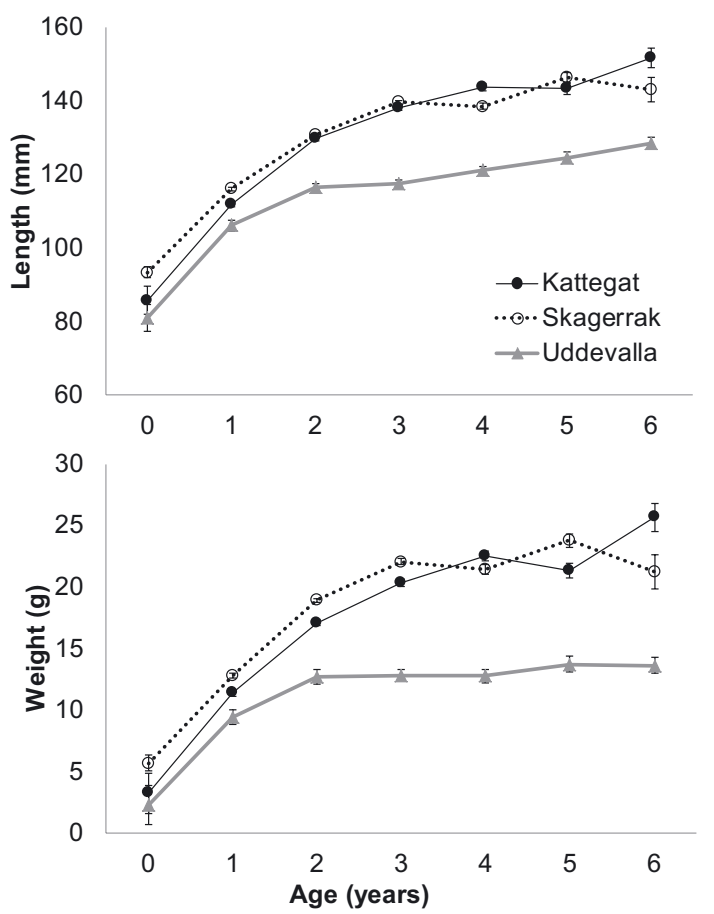

Fig. 6. Growth, in terms of length-at-age $(L A A)$ and weight-at-age $(W A A)$ for the sprat in the Kattegat, Skagerrak and Uddevalla fjords. Vertical bars denote standard errors.

ready present in February, while from March this proportion increased until reaching a peak in April-May in Skagerrak, while in Kattegat intensive spawning protracted until July. The cycle of maturity status showed by our data could have been affected by the different size selectivity of the commercial samples, which included a lower proportion of small fish compared to the research vessels (Appendix, Fig. A.5). During the spawning period, commercial samples were taken in March and April in Kattegat and Skagerrak, and therefore we could have overestimated the relative proportion of mature fish in these months. However, the length of the spawning period estimated by our monthly gonad maturity staging is confirmed by the annual cycle of gonadosomatic index (this study) and conforms to previous studies using eggs and larvae sampling (Sund 1911). For the Uddevalla fjords, samples throughout the year were not available, and therefore we cannot exclude a different duration of the spawning time in this area. In the Uddevalla fjords, however, the proportion of reproductively active fish (stages III-VIII) in May was comparable to that in the Skagerrak and Kattegat ( 70-90\%).

According to the life history theory, individuals allocate their available resources trading-off among growth, reproduction and maintenance to maximize individual fitness (Stearns 1989). This was depicted by our results showing that the body condition and gonadosomatic index of sprat in the SkagerrakKattegat followed opposite yearly patterns, evidencing the annual cycle of energy allocation to somatic versus gonad growth. The period of maximum feeding intensity for planktivorous fish in the northern hemisphere is summer, where the zooplankton reaches the highest biomass (Möllmann et al. 2000) and as a consequence, the peak of the body condition is reached in autumn (Kondratjeva 1993). This was confirmed by 
our results that revealed how sprat in the Skagerrak-Kattegat reached the highest condition in autumn, before overwintering. On the other hand, the peak in reproductive effort (indexed by the GSI) was the lowest in autumn and the highest in MarchJuly, similarly to what found for sprat in other temperate areas, such as the Baltic Sea, southern North Sea and Norwegian coasts (Kondratjeva 1993; George and Alheit 1987; Torstensen 1998; Peck et al. 2012). The inverse pattern in the cycle of somatic versus gonad growth (see for the Baltic Sea Kondratjeva 1993; Haslob et al. 2013) is likely a trade-off between the energy allocation to growth and reproduction. Sprat is an income breeder (Haslob et al. 2013) and as such its reproduction relies not only on stored energy, but also on concomitant food intake. Therefore, the onset of maturation in late winter and early spring relies on the energy stored during the previous growth season and remained from overwintering, while the energy for further gonad development and spawning in late spring and summer (corresponding to the peak in planktonic prey availability) comes directly from food intake (Haslob et al. 2013).

Although the seasonal cycle of energy allocation was similar in the three areas, we found a spatial difference in the absolute amount of energy allocated to growth and reproduction. The Skagerrak sprat had both higher $K$ and GSI, while the Uddevalla fjords sprat the lowest. Likewise, the mean sizes at age (WAA and $L A A)$ were much higher in the Kattegat and Skagerrak than in the Uddevalla fjords. We do not have sufficient elements to fully elucidate the difference in energy allocation between areas, but we provide some potential explanations below. The higher $K$ and GSI of sprat in Skagerrak could suggest that the sprats inhabiting this area have higher availability of resources, which they utilize both to grow quicker and larger and to increase the reproductive output. One of the potential explanations of the higher resource availability could be the higher salinity of the Skagerrak (Appendix, Fig. A.4) that could constitute a suitable environment for a larger variety of prey species (i.e. zooplankton) (Postel 2012; Diaz-Gil 2013). Moreover, the Uddevalla fjords are characterized by a lower water temperature in the summer months (Appendix, Fig. A.4), potentially also affecting plankton production and therefore sprat food availability (Möllmann et al. 2000). It is also noteworthy that the Uddevalla fjords are characterized by deep-water hypoxia and this may have potential negative implications for sprat growth, either directly through metabolic processes (Pichavant et al. 2001) or indirectly by changing the ecological interactions with their planktonic prey (Solberg et al. 2015). However, population internal mechanisms, such as density-dependence (e.g. higher growth in areas with lower fish densities), cannot be excluded, as found for example in the Baltic Sea (Casini et al. 2011). Interestingly, in our study the sprats from the Uddevalla fjords were often heavily affected by the parasite Crympocyle lingua ("black spot disease", unpublished data) whose potential effect on sprat metabolism and thus energy utilization should be further investigated. Currently, the lack of zooplankton and sprat abundance data from the Uddevalla fjords impedes a mechanistic understanding of the observed differences in condition, growth and reproductive effort between areas.

Our data showed that sprat in the study area reach maturity $\left(50 \%\right.$ of fish are mature, $\left.L_{50}\right)$ at a length between 90 $102 \mathrm{~mm}$ (90 mm in the Skagerrak and Kattegat, $102 \mathrm{~mm}$ in the Uddevalla fjords), which is a range similar to that found in other areas, as for example the inshore waters of west Scotland (De Silva 1973), the Norwegian coasts (Torstensen 1998) and the southern Baltic Sea (Grygiel and Wyszyński 2003). In terms of age, almost all sprats (more than 70\%) appeared to be mature as 1-year-old in Skagerrak-Kattegat. This indicates a faster attainment of maturity than for example in the Baltic Sea (ICES 2015b), which is not surprising considering the faster growth of the Skagerrak-Kattegat sprat. Concerning Uddevalla fjord only $45 \%$ of age 1 sprat was maturing probably due to the lower growth rate in this area.

Whether the sprats from the three areas considered in this study constitute three different sub-populations remains unclear. The Skagerrak and Kattegat are largely connected by water exchange both at surface and deep layers, and therefore we argue that it is not likely that the sprat from Skagerrak and Kattegat constitute distinct sub-populations. The sprat from the Uddevalla fjords, on the other hand, could represent a separate sub-population, characterized by a habitat with different abiotic conditions (e.g. lower summer temperature and anoxic deep waters) and limited water exchange with the open sea. The specific biological characteristics of the Uddevalla fjord sprat are lower body growth and reproductive effort (this study; Lindquist 1968) as well as the infection by the black spot disease (Michele Casini pers comm), which indicates a strong sedentary behaviour of this component of the sprat population.

Our results provide important knowledge about the biology of the sprat in Skagerrak-Kattegat which can aid the stock assessment of this species in this area. Particularly, we have provided estimations of maturity ogives (proportion of mature fish by length) in different areas of the Skagerrak-Kattegat at peak spawning. This information can be directly used in the estimation of the spawning biomass (in case an analytical stock assessment is used) or its proxy (in the case an index based on survey is used). With our study we have also furnished information that can help to design a proper data collection sampling scheme for sprat in the study area. For example, since it is important that maturity samples are taken in both the pre-spawning and spawning phases for a proper estimation of the maturity ogives, sprat in Skagerrak-Kattegat should be collected from March to July. Currently, such a sampling is lacking, since scientific surveys in Skagerrak and Kattegat are performed only in January, July and September (ICES 2013, 2015a), and not covering the fjords. Moreover, the observed spatial variation in the individual growth rates and proportion mature at length indicate that individuals from both the Kattegat and Skagerrak, including the fjord systems, must be included in the estimation of the weight-at-age and maturity ogives, as input data for stock assessment. For a conservation perspective, we suggest that genetic studies should be performed to investigate the potential occurrence of different sub-populations (especially between open sea and fjord system) in the area.

Acknowledgements. We thank the personnel on board the Swedish R/V Argos and R/V Ancylus, the Danish R/V Dana, and Swedish commercial boats, for sprat sampling. We are grateful to three anonymous reviewers for constructive comments to a previous version of the paper. 


\section{References}

Avsar D., 1995, Population parameters of sprat (Sprattus sprattus phalericus RISSO) from the Turkish Black Sea coast. Fish Res. 21, 437-453.

Brown-Peterson N.J., Wyanski D.M., Saborido-Rey F., Macewicz B.J., Lowerre-Barbieri S.K., 2011, A standardized terminology for describing reproductive development in fishes. Mar. Coastal. Fish. Dyn. Manag. Ecosys. Sci. 3, 52-70.

Casini M., Cardinale M., Arrhenius F., 2004, Feeding preferences of herring (Clupea harengus) and sprat (Sprattus sprattus) in the southern Baltic Sea. ICES J. Mar. Sci. 61, 1267-1277.

Casini M., Kornilovs G., Cardinale M., Möllmann M., Grygiel W., Jonsson P., Raid T., Flinkman J., Feldman V., 2011, Spatial and temporal density-dependence regulates the condition of central Baltic Sea clupeids: compelling evidence using an extensive international acoustic survey. Popul. Ecol. 53, 511-523.

Dänhardt A., Becker P.H., 2011, Herring and sprat abundance indices predict chick growth and reproductive performance of common terns breeding in the Wadden Sea. Ecosystems 14, 79-803.

De Silva S.S., 1973, Aspects of the reproductive biology of the sprat, Sprattus sprattus $(L$.$) in inshore waters of the west coast of$ Scotland. J. Fish Biol. 5, 689-705.

Diaz-Gil C., Lövgren O., Werner M., Kaljuste O., Margonski P., Casini M., 2014, Spatio-temporal composition and dynamics of zooplankton in the Kalmar Sound (western Baltic Sea) in 2009 2010. Boreal. Environ. Res. 19, 323-335.

Dulčić J., 1998, Larval growth of sprat, Sprattus sprattus phalericus, larvae in the Northern Adriatic. Fish Res. 36, 117-126.

George M.R., Alheit J., 1987, Ovarian maturation cycle of sprat, Sprattus sprattus. ICES C.M. 1987/H: 47.

Grygiel W., Wyszyński M., 2003, Temporal (1980-2001) and geographic variation in the sexual maturity at age and length of herring and sprat inhabiting the southern Baltic. Bulletin of the Sea Fisheries Institute 2, 1-33.

Haslob H., Rabade-Uberos S., Saborido-Rey F., 2013, Seasonal variability of fecundity and spawning dynamics of Baltic sprat. Fish Res. 138, 99-109.

ICES., 2013, Report of the Benchmark Workshop on Sprat Stocks (WKSPRAT), 11-15 February 2013, Copenhagen, Denmark. ICES CM 2013/ACOM:48. 220 p.

ICES, 2015a, Report of Herring Assessment Working Group (HAWG) 10-19 March 2015. ICES HQ, Copenhagen, Denmark. ICES CM 2015/ACOM:06, p. 850.

ICES, 2015b, Report of the Baltic Fisheries Assessment Working Group (WGBFAS), 14-21 April 2015, ICES HQ, Copenhagen, Denmark. ICES CM 2015/ACOM:10, p. 816.

Kondratjeva N., 1993, Biochemical and morphophysiological parameters of Baltic sprat in relation to age and annual cycle periods. ICES C.M. 1993/J: 25.

Kraus G., Köster F.W., 2004, Estimating Baltic sprat (Sprattus sprattus balticus $\mathrm{S}$.) population sizes from egg production. Fish Res. 69, 313-329.

Lindquist A., 1964, Zur Fischerei Hydrografie der Sprotte (Clupesa sprattus) an der schwedischen Westküste. In Series Biologi. Lysekil: Institute of Marine Research.

Lindquist A., 1966, Jahresklassen der Sprotte (Clupea sprattus) an der schwedischen Westküste in den Fängen 1929-1965. In Series Biology. Lysekil: Institute of Marine Research.

Lindquist A., 1968, Meristic and Morphometric Characters, Yearclasses and "Races" of the Sprat (Sprattus sprattus) In Series Biology. Lyskekil: Institute of Marine Research.
Lindquist A., 1970, Zur Verbreitung der Fischeier und Fischlarven im Skagerak in den Monaten Mai und Juni. In Series Biology, pp. 1-81. Lysekil: Institute of Marine Research.

Lindquist A., 1972, Growth rate changes of sprat in the SkagerrakKattegat. ICES CM H:27.

Lundström K., Hjerne O., Lunneryd S.-G., Karlsson O., 2010, Understanding the diet composition of marine mammals: grey seals (Halichoerus grypus) in the Baltic Sea. ICES J. Mar. Sci. 67:1230-1239.

MacKenzie B.R., Horbowy J., Köster F.W., 2008, Incorporating environmental variability in stock assessment: predicting recruitment, spawner biomass, and landings of sprat (Sprattus sprattus) in the Baltic Sea. Can. J. Fish Aquat. Sci. 65, 1334-1341.

Molander A.R., 1940, A Research upon the Sprat of the West Coast of Sweden I. In: Svenska Hydrografisk-Biologiska Kommissionens Skrifter. Lysekil.

Molander A.R., 1942, A Research upon the Sprat of the West coast of Sweden II. In Svenska Hydrografisk-Biologiska Kommissionens Skrifter. Lysekil.

Möllmann C., Kornilovs G., Sidrevics L., 2000, Long-term dynamics of main mesozooplankton species in the central Baltic Sea. J. Plankton Res. 22, 201-2038.

Peck M.A., Baumann H., Bernreuther M., Clemmesen C., Herrmann J.-P., Haslob H., Huwer H., Kanstinger P., Köster F.K., Petereit C., Temming A., Voss R., 2012, The ecophysiology of Sprattus sprattus in the Baltic and North Seas. Prog. Oceanogr. 103, 42-57.

Pichavant K., Person-Le-Ruyet J., Le Bayon N., Severe A., Le Roux A., Boeuf G., 2001, Comparative effects of long-term hypoxia on growth, feeding and oxygen consumption in juvenile turbot and European sea bass. J. Fish Biol. 59, 875-888.

Postel L., 2012, Mesozooplankton diversity, reproduction modes, and potential invisibility in the Baltic Sea. Cah. Biol. Mar. 53, 327-336.

Power M., Attrill M.J., Thomas R.M., 2000, Temporal abundance and growth of juvenile herring and sprat from the Thames estuary 1977-1992. J. Fish Biol. 56, 1408-1426.

Shulman G.E., Nikolsky V.N., Yuneva T.V., Minyuk G.S., Shchepkin V.Y., Shchepkin A.M., Ivleva E.V., Yunev O.A., Dobrovolov I.S., Bingel F., Kideys A.E., 2005, Fat content in Black Sea sprat as an indicator of fish food supply and ecosystem condition. Mar. Ecol. Prog. Ser. 293, 201-212.

Solberg I., Røstad A., Kaartvedt S., 2015, Ecology of overwintering sprat (Sprattus sprattus). Prog. Oceanogr. 138, 116-135.

Stearns S.C., 1989, Trade-Offs in Life-History Evolution. Funct. Ecol. 3, 259-268.

Sund O., 1911, Undersøkelser over brislingen I norske farvand væsentlig paa grundlag av "Michael Sars"s togt 1908. Med tabeller over forekomst af egg og yngel fra "Michael Sars"togt 1908 av Einar Koefoed. Aarsberetn. Vedk. Norges fiskerier för 1910 3, 357-474.

Torstensen E., 1998, Growth and maturity of sprat in Norwegian coastal waters. ICES CM 1998, CC:19.

Torstensen E., Gjøsæter J., 1995, Occurrence of 0-group sprat (Sprattus sprattus) in the littoral zone along the Norwegian Skagerrak coast 1945-1992, compared with the occurrence of 0group herring (Clupea harengus). Fish Res. 21, 409-421.

Vitale F., Börjesson P., Svedäng H., Casini M., 2008, The spatial distribution of cod (Gadus morhua L.) spawning grounds in the Kattegat, eastern North Sea. Fish Res. 90, 36-44. 


\section{Appendix}

Table A.1. Modified maturity scale, originally developed for herring and recommended by ICES in 1962.

\begin{tabular}{cl}
\hline Stage & \multicolumn{1}{c}{ Description } \\
\hline I & $\begin{array}{l}\text { Virgin. Gonads very small, threadlike, 2-3 broad. } \\
\text { Ovaries wine red. Testes whitish or grey brown. }\end{array}$ \\
\hline II & $\begin{array}{l}\text { Sexual organs still small. Height of ovaries and testes } \\
\text { about 3-8 mm. Eggs not visible to naked eye but can be } \\
\text { seen with a magnifying glass. Ovaries a bright red } \\
\text { colour; testes a reddish grey colour. }\end{array}$ \\
\hline III & $\begin{array}{l}\text { Gonad occupying about a half of ventral cavity. Breadth } \\
\text { of sexual organs between 1 and 2 cm. Eggs small but } \\
\text { can be distinguished with naked eye. Ovaries orange; } \\
\text { testes grey or greyish. }\end{array}$ \\
\hline IV & $\begin{array}{l}\text { Gonads almost as long as body cavity. Eggs larger, } \\
\text { varying in size, opaque. Ovaries orange or pale yellow; } \\
\text { testes whitish. }\end{array}$ \\
\hline V & $\begin{array}{l}\text { Egg large, round; some transparent. Ovaries yellowish } \\
\text { testes milk white. Eggs and sperm do not flow, but } \\
\text { sperm can be extruded by pressure. }\end{array}$ \\
\hline VI & $\begin{array}{l}\text { Ripe gonads. Eggs transparent; testes white; eggs } \\
\text { and sperm flow freely. }\end{array}$ \\
\hline VII & $\begin{array}{l}\text { Spent. Gonads baggy and bloodshot. Ovaries empty or } \\
\text { containing only few residual eggs. Testes may contain } \\
\text { remain of sperm. }\end{array}$ \\
\hline VIII & $\begin{array}{l}\text { Recovering spent. Ovaries and testes firm and larger } \\
\text { than in Stage II. Eggs not visible to naked eye. Walls of } \\
\text { gonad striated; blood vessels prominent. Gonads wine } \\
\text { red colour. (This stage passes into Stage II) }\end{array}$ \\
\hline &
\end{tabular}

Table A.2. Results of the GLM for analyzing the annual cycle in Fulton's condition factor $(K)$ in the study area. In bold are the independent variables, in regular font the covariates. Sum of squares (SS), degrees of freedom $(d f)$, mean square (MS), $F$-value and significance $(p)$ are provided.

\begin{tabular}{cccccc}
\hline$K$ cycle $($ GLM $)$ & SS & $d f$ & MS & $F$ & $p$ \\
\hline Month & 20.77 & 10 & 2.08 & 236.06 & $<0.0001$ \\
Year & 1.56 & 1 & 1.56 & 177.60 & $<0.0001$ \\
Area & 0.02 & 1 & 0.02 & 2.11 & 0.15 \\
Total length & 0.29 & 1 & 0.29 & 33.40 & $<0.0001$ \\
Sex & 0.54 & 1 & 0.54 & 61.43 & $<0.0001$ \\
\hline$F(10,3554)=236.06$ & & & & \\
\hline
\end{tabular}

Table A.3. Results of the GLM for analyzing the annual trends in Gonadosomatic index (GSI) in the study area. In bold are the independent variables, in regular font the covariates. Sum of squares (SS), degrees of freedom $(d f)$, mean square (MS), $F$-value and significance $(p)$ are provided.

\begin{tabular}{cccccc}
\hline GSI cycle (GLM) & SS & $d f$ & MS & $F$ & $p$ \\
\hline Month & 1505.74 & 10 & 150.57 & 759.69 & $<0.0001$ \\
Year & 0.50 & 1 & 0.50 & 2.52 & 0.11 \\
Area & 39.12 & 1 & 39.12 & 197.37 & $<0.0001$ \\
Total length & 78.03 & 1 & 78.03 & 393.70 & $<0.0001$ \\
Sex & 39.31 & 1 & 39.31 & 198.34 & $<0.0001$ \\
\hline$F(10,3554)=759.69$ & \multicolumn{7}{c}{} \\
\hline
\end{tabular}

Table A.4. Results of the GLM and Post-hoc test for comparison of Fulton's condition factor $(K)$ between Skagerrak, Kattegat and Uddevalla fjords. For the GLM, in bold is the independent variable, in regular font the covariates. Sum of squares (SS), degrees of freedom $(d f)$, mean square (MS), $F$-value and significance $(p)$ are provided. For the Post-hoc test, the $p$-vales of the pairwise comparison between areas are provided. Only May data, corresponding to peak spawning and sampled by sampled by the RV Ancylus, were used.

\begin{tabular}{cccccc}
\hline$K$ comparison (GLM) & SS & $d f$ & MS & $F$ & $p$ \\
\hline Area & 4.66 & 2 & 2.33 & 43.08 & $<0.0001$ \\
Year & 8.31 & 1 & 8.31 & 153.76 & $<0.0001$ \\
Total length & 3.68 & 1 & 3.68 & 68.14 & $<0.0001$ \\
Maturity stage & 0.56 & 1 & 0.56 & 10.31 & $<0.01$ \\
Sex & 0.36 & 1 & 0.36 & 6.72 & $<0.01$ \\
\hline$F(2,471)=43.08$ & & & & & \\
\hline
\end{tabular}

\begin{tabular}{ccccc}
\hline$K$ comparison (Post-hoc test) & & & \\
\hline Area & Mean & Kattegat & Skagerrak & Uddevalla \\
\hline Kattegat & 2.89 & & $<0.01$ & $<0.0001$ \\
Skagerrak & 3.04 & $<0.01$ & & $<0.0001$ \\
Uddevalla & 3.13 & $<0.0001$ & $<0.0001$ & \\
\hline MS = $0.054 ; d f=471$ & & & & \\
\hline
\end{tabular}

Table A.5. Results of the GLM and Post-hoc test for comparison of Gonadosomatic index (GSI) between Skagerrak, Kattegat and Uddevalla fjords. For the GLM, in bold is the independent variable, in regular font the covariates. Sum of squares (SS), degrees of freedom $(d f)$, mean square (MS), $F$-value and significance $(p)$ are provided. For the Post-hoc test, the $p$-vales of the pairwise comparison between areas are provided. Only May data, corresponding to peak spawning and sampled by the sampled by the RV Ancylus, were used.

\begin{tabular}{cccccc}
\hline GSI comparison (GLM) & SS & $d f$ & MS & $F$ & $p$ \\
\hline Area & 1.29 & 2 & 0.65 & 33.88 & $<0.0001$ \\
Year & 0.21 & 1 & 0.21 & 11.22 & $<0.001$ \\
Total length & 0.17 & 1 & 0.17 & 8.78 & $<0.01$ \\
Maturity stage & 22.74 & 1 & 22.74 & 1193.67 & $<0.0001$ \\
Sex & 0.40 & 1 & 0.40 & 20.96 & $<0.0001$ \\
\hline$F(2,471)=33.88$ & & & & &
\end{tabular}

\begin{tabular}{ccccc}
\hline GSI comparison (Post-hoc test) & & & \\
\hline Area & Mean & Kattegat & Skagerrak & Uddevalla \\
\hline Kattegat & 0.82 & & $<0.05$ & $<0.001$ \\
Skagerrak & 0.78 & $<0.05$ & & $<0.001$ \\
Uddevalla & 0.60 & $<0.0001$ & $<0.0001$ & \\
\hline MS = $0.019 ; d f=471$ & & & & \\
\hline
\end{tabular}


Table A.6. Results of the GLM and Post-hoc test for comparison of length-at-age (LAA) between Skagerrak, Kattegat and Uddevalla fjords. For the GLM, in bold are the independent variables, in regular font the covariates. Sum of squares (SS), degrees of freedom $(d f)$, mean square (MS), $F$-value and significance $(p)$ are provided. For the Post-hoc test, the mean values and the $p$-vales of the pairwise comparison between areas are provided by age. Only May and October/November data, sampled by the RV Ancylus, were used.

\begin{tabular}{|c|c|c|c|c|c|c|c|c|}
\hline & \multicolumn{2}{|c|}{$L A A$ comparison $(\mathrm{GLM})$} & SS & $d f$ & MS & $F$ & $p$ & \\
\hline & \multicolumn{2}{|c|}{ Area } & 35745.22 & 2 & 17872.61 & 178.43 & $<0.0001$ & \\
\hline & \multicolumn{2}{|c|}{ Age } & 185323.09 & 6 & 30887.18 & 308.37 & $<0.0001$ & \\
\hline & \multicolumn{2}{|c|}{ Age*Area } & 12312.48 & 12 & 1026.04 & 10.24 & $<0.0001$ & \\
\hline & \multicolumn{2}{|c|}{ Year } & 589.48 & 1 & 589.48 & 5.89 & $<0.05$ & \\
\hline & \multicolumn{2}{|c|}{ Month } & 43773.30 & 1 & 43773.30 & 437.02 & $<0.0001$ & \\
\hline & \multicolumn{2}{|c|}{ Sex } & 25693.78 & 1 & 25693.78 & 256.52 & $<0.0001$ & \\
\hline & \multicolumn{3}{|c|}{$F(12,1084)=10.24$} & & & & & \\
\hline \multicolumn{9}{|c|}{ LAA comparison (Post-hoc test) } \\
\hline \multicolumn{4}{|c|}{ Age 0 } & \multicolumn{3}{|c|}{ Age 4} & & \\
\hline & Kattegat & Skagerrak & Uddevalla & \multirow{2}{*}{\multicolumn{2}{|c|}{ Kattegat }} & \multirow[t]{2}{*}{ Kattegat } & Skagerrak & \multirow[t]{4}{*}{ Uddevalla } \\
\hline Kattegat & & & & & & & & \\
\hline Skagerrak & 0.73 & & & & agerrak & 0.25 & & \\
\hline Uddevalla & 1.00 & 0.41 & & & Idevalla & $<0.0001$ & $<0.0001$ & \\
\hline \multirow[t]{2}{*}{ Age 1 } & & & & \multicolumn{2}{|c|}{ Age 5 } & & & \\
\hline & Kattegat & Skagerrak & Uddevalla & \multirow{2}{*}{\multicolumn{2}{|c|}{ Kattegat }} & Kattegat & Skagerrak & Uddevalla \\
\hline Kattegat & \multirow{2}{*}{\multicolumn{2}{|c|}{$<0.0001$}} & & & & & & \\
\hline Skagerrak & & & & \multicolumn{2}{|c|}{ Skagerrak } & 1.00 & & \\
\hline Uddevalla & 0.63 & $<0.0001$ & & & Idevalla & $<0.0001$ & $<0.0001$ & \\
\hline \multirow[t]{2}{*}{ Age 2} & & & & \multicolumn{2}{|c|}{ Age 6} & & & \\
\hline & Kattegat & Skagerrak & Uddevalla & & & Kattegat & Skagerrak & Uddevalla \\
\hline Kattegat & & & & & attegat & & & \\
\hline Skagerrak & 1.00 & & & & agerrak & 0.90 & & \\
\hline Uddevalla & $<0.0001$ & $<0.0001$ & & & Idevalla & $<0.0001$ & 0.742625 & \\
\hline \multicolumn{4}{|l|}{ Age 3} & & & & & \\
\hline & Kattegat & Skagerrak & Uddevalla & & & & & \\
\hline \multicolumn{4}{|l|}{ Kattegat } & & & & & \\
\hline Skagerrak & \multicolumn{3}{|l|}{1.00} & & & & & \\
\hline Uddevalla & $<0.0001$ & $<0.0001$ & & & & & & \\
\hline \multicolumn{4}{|c|}{$\mathrm{MS}=100.16 ; d f=1065$} & & & & & \\
\hline
\end{tabular}

Table A.7. Summary of the results of the GLM and Post-hoc test for comparison of weight-at-age (WAA) between Skagerrak, Kattegat and Uddevalla fjords. For the GLM, in bold are the independent variables, in regular font the covariates. Sum of squares (SS), degrees of freedom $(d f)$, mean square (MS), $F$-value and significance $(p)$ are provided. For the Post-hoc test, the mean values and the $p$-vales of the pairwise comparison between areas are provided by age. Only May and October/November data, sampled by the RV Ancylus, were used.

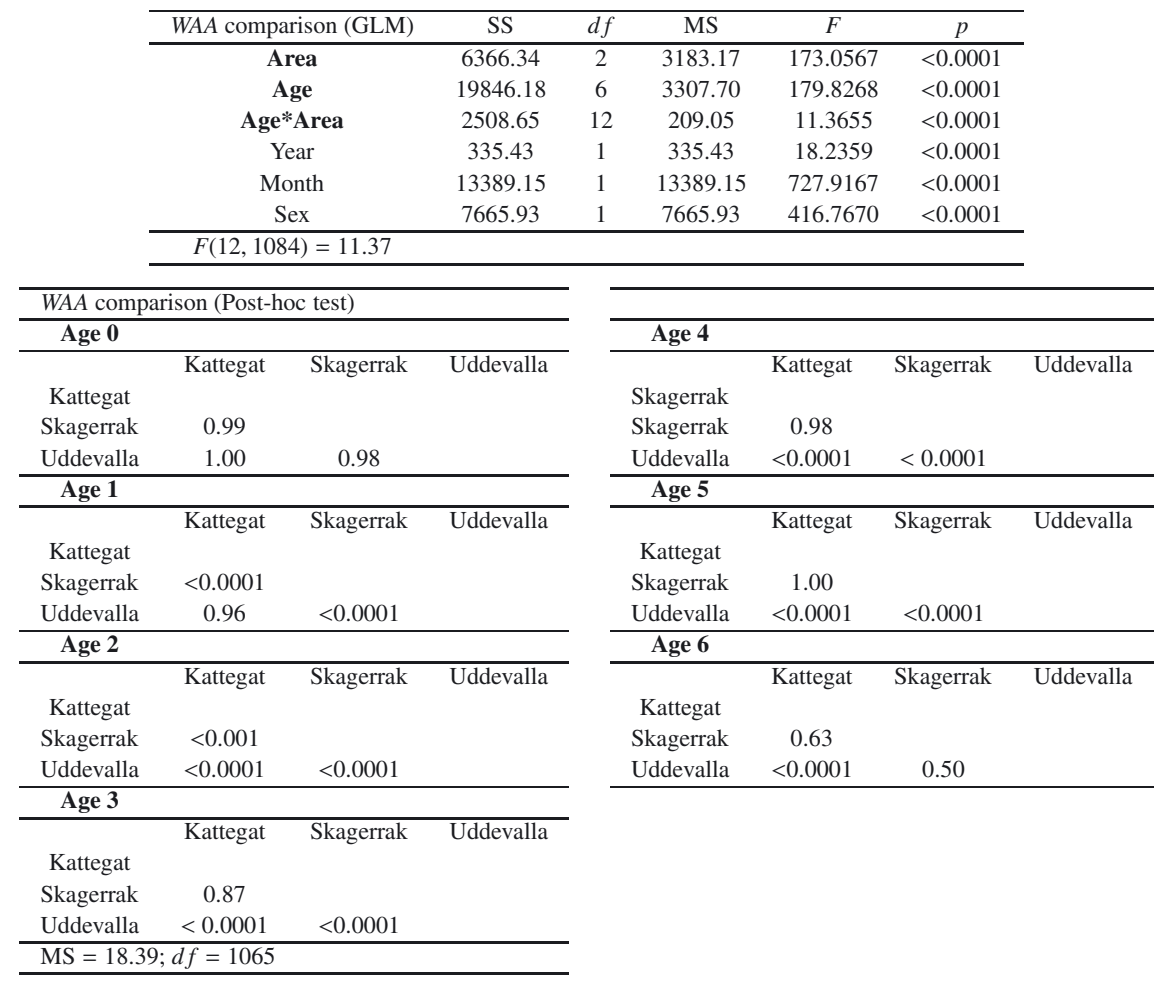




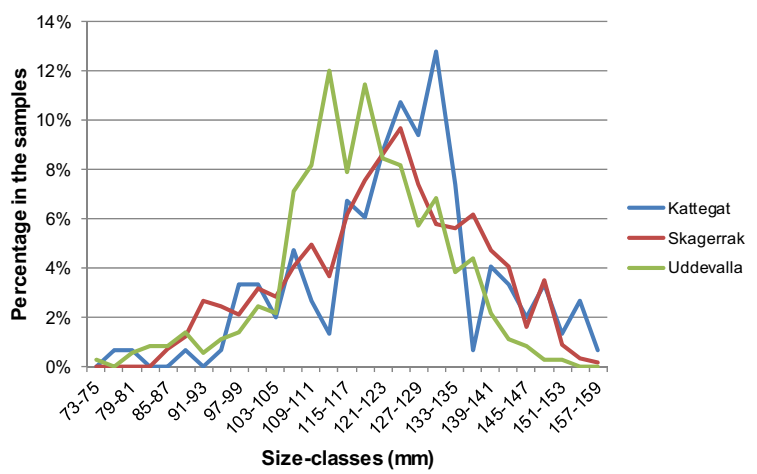

Fig. A.1. Length frequency distribution of the sprat collected in May and October/November in the three investigated areas, by the R/V Ancylus. These were the months used in the comparisons of the biological parameters $(K, G S I, L A A$ and $W A A)$ between the three areas.

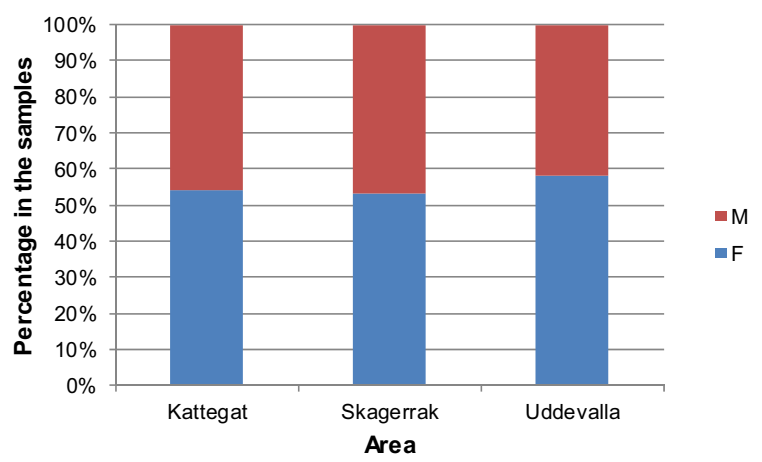

Fig. A.3. Sex ratio of the sprat collected in May and October/ November in the three areas investigated, by the R/V Ancylus.
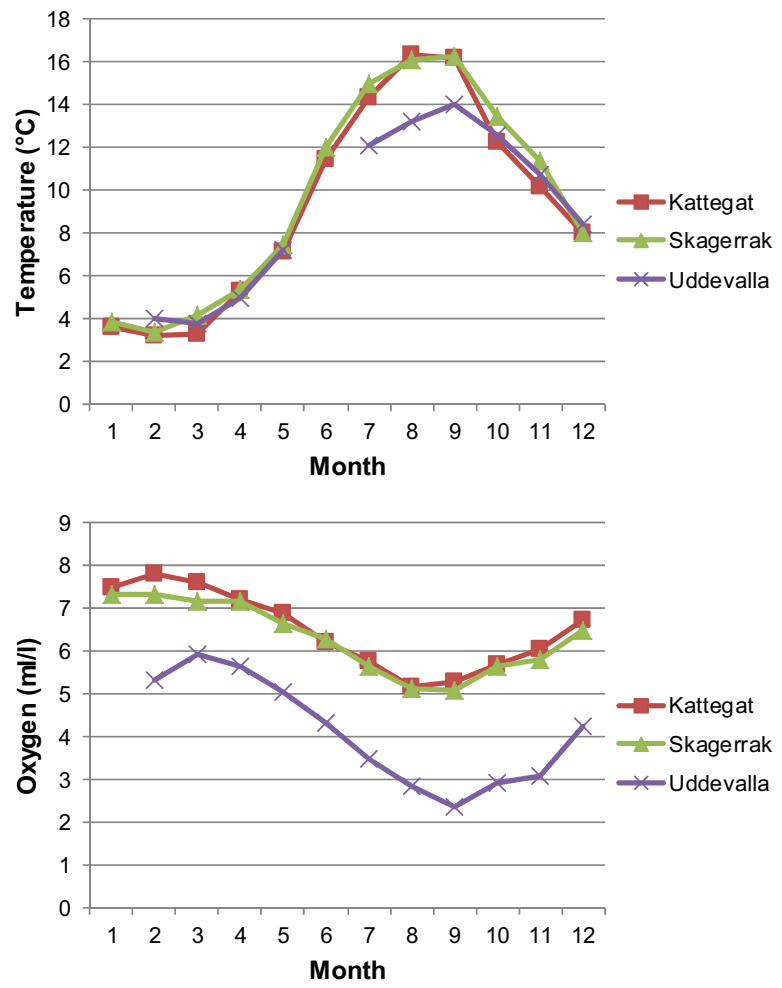

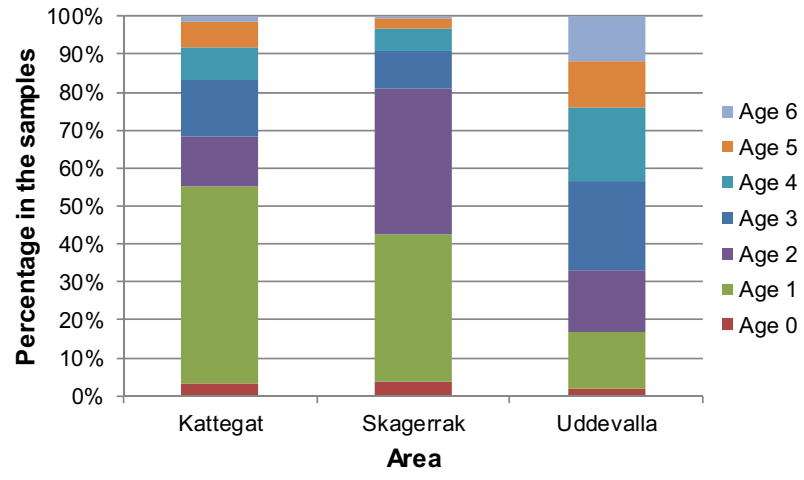

Fig. A.2. Age structure of the sprat collected in May and October/ November in the three areas investigated, by the R/V Ancylus.

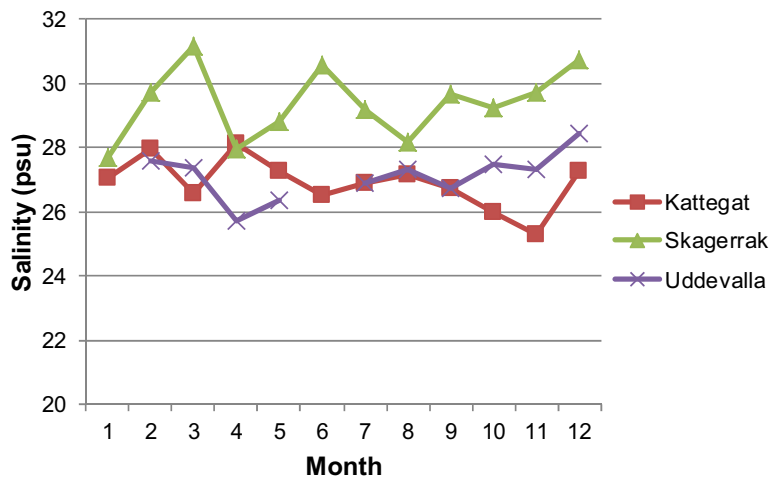

Fig. A.4. Temperature, salinity and oxygen seasonal patterns in 2003-2004 (average 0-30 m). 


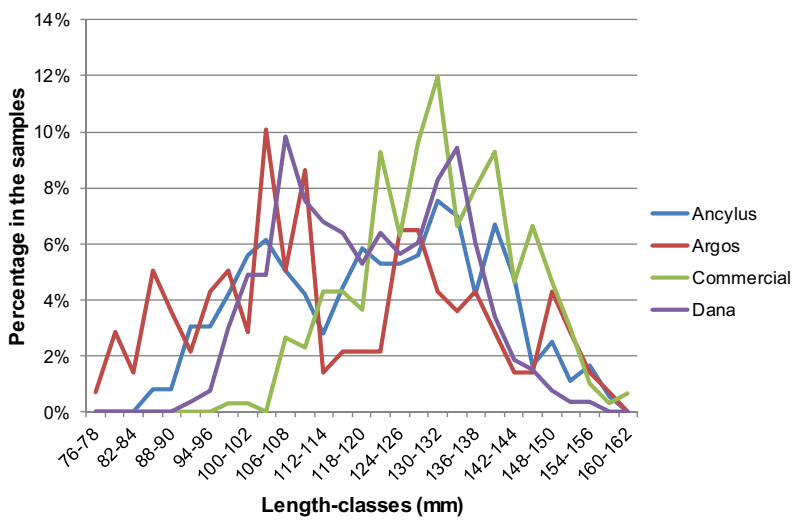

Fig. A.5. Length frequency distribution of the sprat collected in April-July by the four different vessels (commercial vessels pooled together).

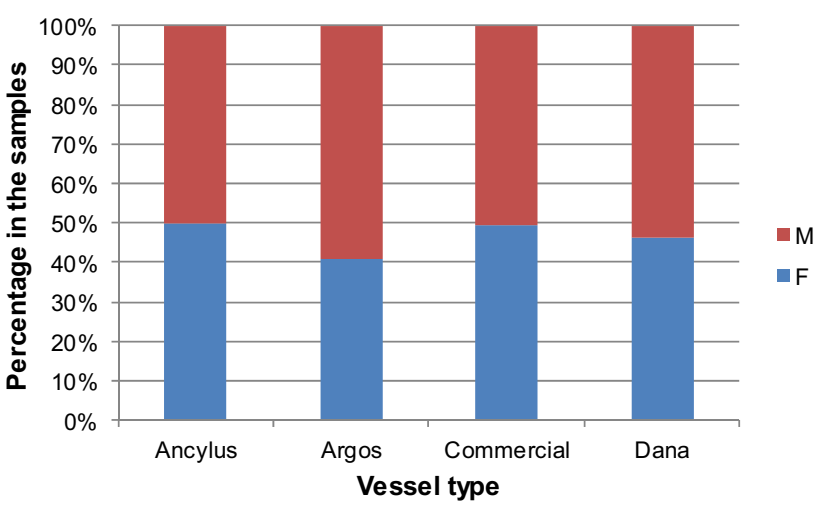

Fig. A.6. Sex ratio of the sprat collected in April-July by the four different vessels (commercial vessels pooled together). 